\title{
Sealing Leakages of Public Funds Abuse: The Malawi "Cashgate" Case
}

\author{
Byson B. Majanga $^{1}$ \\ ${ }^{1}$ Accountancy Department-University of Malawi, Malawi \\ Correspondence: Byson B. Majanga, Accountancy Department-University of Malawi, Malawi.
}

Received: January 5, 2015

Accepted: January 19, 2015

Available online: March 17, 2015

doi:10.11114/afa.v1i2.726

URL: http://dx.doi.org/10.11114/afa.v1i2.726

\begin{abstract}
The accountancy profession subscribes to the values of accountability, integrity, honesty, accuracy among others and that is the reason accountants are required in any field of work to provide an independent report of how the resources are deployed to bring the outcome and assess if indeed the outcome from the use of such resources is as it had been expected by all the stakeholders. This requirement is common to all sectors of the economy, whether in the public or private sector.

The paper discusses the changing role of the accountant in the public sector in response to the growing concerns of public resource abuse. Africa, Malawi in particular, has been a victim of gross resource abuse by public officers through among others fraud, corruption, theft and gross mismanagement. Malawi has recently been rated highly in terms of corrupt practices with the public sector taking a leading position leading to gross mismanagement of public resources since the dawn of democracy in 1994.

The study takes a look at the changing roles of an accountant in the public sector where the control environment in the financial management system, and the political will of those in charge of the public sector, are not the same as those in the private sector.

The accounting weaknesses or challenges as revealed by the reviewed audit reports are scrutinised and the role of the accountant with respect to each challenge is reviewed and recommendations suggested which if implemented, may block the future recurrence of such weaknesses in the financial management systems in the public sector.
\end{abstract}

Keywords: Public sector; public funds; internal control; ethical behaviour; value for money.

\section{The Twenty First Century Accountant}

An accountant has been understood to be someone involved mainly with playing with numbers and figures, keeping the figures in a systematic process and finally producing reports to stakeholders based on what the figures and numbers communicate. According to Wikipedia, accounting is defined as the keeping or preparation of the financial records of an entity, the analysis, and verification and reporting of such records (http://en.wikipedia.org/wiki/Accountant)

The roles of an accountant in the twenty first century are no longer as they were is the late 80's due to the complexity of the business environment and operations. In the twenty first century, the business environment has become very complex and competitive than it was before. The levels of corruption have risen to the highest levels in the latter years than they were in the 80 's although the fight against corruption has been intensified. The pressure from the political party gurus is also mounting on the technocrats both in the government as well as in the private sector as such there are more deviations in doing business from the normal and established paths.

The most important problem is that in the public sector, the politician, who happens to have more influence on the running of public funds than the technocrats themselves, has a relatively short time horizon which normally does not exceed the date of the next election whereas the technocrat, who is a professional manager, is concerned with the long term success of the entity he or she is managing (Hepworth N, 1993). This asynchronous time frame of interests causes challenges to professional managers including accountants in executing their duties.

In addition, the extreme dependency on information technologies has also shifted the focus of accountants (The Economist Intelligence Unit), especially now that the world has become a global village. These factors have caused the operating environment for accountants to become more complex than it was before.

An accountant now is not solely a number cruncher or an auditor; he is also a management accountant, a business leader, 
a corporate financier, and a business advisor (International Federation of Accountants 2005). In this twenty first century, accountants are no longer restricted to keeping and maintaining records but have expanded their horizons in all directions. Accountants are now involved with financial and investment decision making, business analysis and strategy formulation, information technology planning, business consulting, as well as provision of advisory services (Economist Intelligence Unit).

The International Federation of Accountants (IFAC) defines a professional accountant as an individual who has skills, knowledge, and expertise tested by examination and continuously developed in a structured and monitored context; committed to the values of accuracy, honesty, integrity, objectivity, transparency, and reliability; subject to oversight by a body with disciplinary powers (IFAC 2005 pp 2). It is therefore evident that every role in the professional life embraces attitudes and behaviours, and that the role practitioner, the accountant, is presumed to act in a relatively standardised way in different situations (Andreasson, L. and Bladh, A. 2005).

It has to be appreciated that an accountant can play his or her roles in the commercial or public sector and according to Andreasson, L. and Bladhl, A. 2005, other than the technical nature of the roles, the accountant is expected to demonstrate similar skills and values of accuracy, honesty, integrity, objectivity, transparency and reliability, the type of sector notwithstanding. The use of cash or accrual basis of accounting and budgeting was seen as a great divide between the two sectors with the public mostly practising the cash basis and the private or commercial practising the accruals (Bridsel, R. G., Popa, A., and Pop, A ). This distinction however does not take away any grain of professionalism from the accountant as he or she changes sectors.

In the public sector, the tasks of an accountant mainly revolve around financial management and if the accountants define their role either implicitly or explicitly in traditional terms as a keeper or inspector of accounts, then they are not able to provide the style of expertise which the modern public sector now requires (Hepworth, N. 1993).

\section{The Malawi Public Sector}

The public sector is a section of a national economy which provides services that are produced to benefit all the citizenry and one cannot separate the persons using the services from those not using them (Andreasson, L., and Bladh, A. 2005).

According to the Malawi Public Service Charter, the Malawi public service consists of the civil service, the parastatals, the judicial service, parliamentary service, the Malawi Defence Forces, immigration and prison services, and the constitutional bodies. These constituents of the Malawi public sector get funding from the Malawi government for their operations in the quest to provide efficient services to the general public. The paper is focusing much on the main constituent of the Malawi public sector, which is the mainstream civil service.

The measure of performance in these institutions may not be similar to that of institutions in the private sector because in the public sector, the accountant is mostly concerned with proper and efficient management of the financial resources as he is achieving the objectives of the institution. The main information available to the accountant and manager is therefore about inputs and outputs and in these circumstances he needs a comparative yardstick to evaluate performance (Hepworth, N. 1993). The accountant therefore compares the performance for the current year against that of the previous year to assess the overall performance of the institution.

The challenge that accountants face in the public sector is the achievement of the value for money (VFM) which is an expression of the economy, the efficiency, and the effectiveness with which the institutions operate. It is expected that as a public sector institution is in operation, the professional manager in charge, or the accountant must always strive to spend on high quality goods or services at the lowest cost possible, maximise the use of the goods or services acquired for the benefit of the institution, as well as making sure that the general public, which the institution was created to serve, is finally benefiting from, and satisfied with the functions of the institution.

A thorough financial analysis of Malawi public sector institutions shows that most institutions are operating below the VFM target of economy, efficiency and effectiveness. Audit reports have for a long period of time shown that procurement procedures in the public sector institutions are being bypassed to the extent that institutions acquire services and goods from nonexistent suppliers at a price double as much as the normal market price. This has led to government ministries and departments reporting high over expenditures annually, the benefits of which do not reach the citizens.

The table below provides a summary of over expenditures recorded during the fiscal year 2006/2007 
Table 1. Public Sector Over expenditure

\begin{tabular}{ll}
\hline Institution & Over expenditure (\% of annual budget)) \\
\hline Civil service-ministries and departments & 52.02 \\
Judiciary & 12.21 \\
Parliamentary & 30.29 \\
Constitutional bodies & 5.48 \\
\hline
\end{tabular}

Source: Report of the Auditor General June 2007

Over expenditure on the other hand cannot always be construed as adverse as it sometimes indicates the level of operational effectiveness of the institution. An in-depth review of audit reports has shown however that most expenditure, especially on procurement of goods and services, made by the institutions was not approved or not supported by proper documents. The benefits of such expenditures therefore could hardly be traced to a particular outcome to the general public.

This is a shortfall on the Economic part of the VFM matrix. This practice is on the increase in the public sector besides the fact that Malawi as a country scored highly on the Transparency International Report in having a good legal framework in place for ensuring public procurement effectiveness (Nawarz, F. 2012).

\section{The Malawi "Cashgate" Scandal}

In mid-2013, the public got shocked by reports that huge sums of public money were carelessly plundered by government officials who were supposed to be the custodians of the same. An investigation into the same discovered a lot of weaknesses in the Integrated Financial Management System (IFMIS) used by the government in its financial transactions which included theft of hard cash by unauthorised cashing of cheques, inflation of procurement prices, as well as cash payments without proper supporting documents.

The investigations revealed total fund wastage of about K13 billion which were analysed as follows:

Table 2. Composition of the Cashgate Scandal

\begin{tabular}{ll}
\hline Type of transaction & \% composition \\
\hline Cashgated amounts (theft) & 45 \\
Payments with no supporting documents & 29 \\
Inflated procurement prices & 26 \\
\hline
\end{tabular}

Source: Baker Tilly report on cashgate 2014

\section{Internal Controls and the Cashgate}

The cashgate scandal, though erupted in 2013 must have started a long time back as evidenced by the findings below. The weaknesses and challenges that this paper analyses were there before the cashgate was exposed and this explains the persistent existence of overall weak internal controls in the government financial management system.

The most crucial component of an internal control system in a business entity or in public sector entity is the control environment which includes the integrity, ethical values and competence of the people within it; management's philosophy and operating style; the way management assigns authority and responsibility, and organizes and develops its people; and the attention and direction provided by the board of directors (Marian, S. F., Carmen, T., Gabriel, B., and Mihai, V. 2010).

The Integrated Financial Management system which was instituted and implemented by the Malawi Government in 2005 was found to be weak and experts reported that the system did not have any alert system to detect any fraudulent activities or any deviations from normal operations within the system, such as overriding system controls without appropriate approval process. In addition, the IFMIS infrastructure did not have any intrusion prevention and detective system or mechanism to easily gain visibility and monitor any potential security threats as such, the access in it was mainly by user ID and password which could easily be accessed (Phiri, M. and Chisala, R. 2009)

Much as the IFMIS had its own control weaknesses, it was the people behind its use who did not consider the need to act professionally as the control environment includes the people in authority who oversee the operations of the controls.

The cash gate investigation report indicated weaknesses in the control environment especially where other controls were deliberately paralysed just to allow a certain transaction to be completed. The report shows that among others, cash withdrawals which exceeded the set limits were allowed to be processed by the commercial banks and even though suspicions were reported to the relevant authorities, no tangible actions were taken to curb the practice. (Baker Tilly Report, 2014)

As already highlighted in the paper, the cashgate scandal was just the climax of public resource mismanagement by public officers. This practice had been in existence before and the cashgate scandal was just an awareness point for the 
general public to know the weaknesses within their own government's financial system.

\section{Accounting Challenges/Weaknesses from Audit Reports}

The paper analyses the main audit irregularities as reported by the country's sole Supreme Audit Institution, the National Audit Office, which is required to audit and report on the public accounts of the Government of Malawi and to exercise such other powers in relation to the public accounts and accounts of other public authorities and bodies as may be prescribed by an Act of Parliament, in so far as they are compatible with its principle duties (The Malawi Constitution Section 184(1)).

The purpose of an audit is to identify areas of weaknesses within the accounting systems and recommend the improvement of the same and not to get involved in the mainstream activities of the entity being audited. It is the responsibility of the professional manager or the controlling officer to ensure that all systems are properly controlled in order to realise the goals of the entity which are an integral part of the value for money. The accountant therefore has to ensure that internal controls are put in place and are designed to address risks and to provide reasonable assurance that in pursuit of its mission, the entity is able to execute orderly, ethical, economical, efficient and effective operations; to fulfil its accountability obligations, to comply with applicable laws and regulations, and to safeguard the public resources against loss, misuse and damage (Vanstapel, F. 2004)

The paper analysed several audit irregularities and accounting weaknesses which have been categorised into seven major challenges, unrecorded/unaccounted for transactions (C1), payments with no supporting documents (C2), misappropriations and theft (C3), Payments to ghost workers/suppliers (C4), transactions not presented for audit (C5), misallocated funds (C6), and unauthorised payments/transactions (C7). These irregularities for the four years under review, that is, 2007 through to 2011 amounted to a total of K1.5 billion Malawi Kwacha ${ }^{1}$ which if properly accounted for as required would have improved the performance of the entire public sector in Malawi.

\subsection{Challenge C1, Unrecorded Transaction and Items Unaccounted For}

Of the seven challenges, the most outstanding from the review of the audit reports was that of "unrecorded and/or unaccounted for transactions (C1)". Most of the elements that were not accounted for by the responsible officers were cash, fuel and other stores items. This irregularity made up to $43.2 \%$ of total irregularities in terms of monetary values as shown in the figure below:

\section{Proportion of accounting challenges 2007-2011}

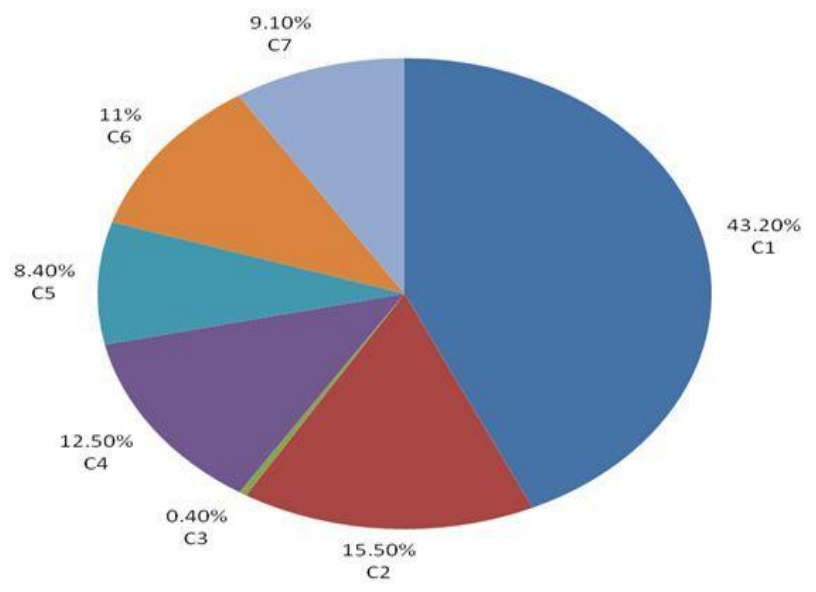

Figure 1. Composition of audit irregularities from 2007 to 2011

Source: Auditor General's annual audit reports of the Malawi Government 2007-2011

The major task in the accounting process involves the routine recording of transactions as they occur and the keeping of transactions on proper records helps to provide evidence of the occurrence and existence of the transaction (Millichamp, A. H., and Taylor, J. R. 2008). As proper recording of transactions is an element of internal control system, it is expected that this should be everyone's responsibility. The Accountant is ultimately responsible and should assume ownership of the system more than any other individual as he or she sets the tone at the top that affects integrity and

${ }^{1}$ The total amount could be higher than this as the paper considered only the material amounts arising from material irregularities. 
ethics and other factors of a positive control environment. (Marian, S. F., Carmen, T., Gabriel, B., and Mihai, V. 2010)

Reports indicate that the accounting system, called IFMIS, that had been in use in the government accounts before the "cashgate" scandal in 2013 had lots of loopholes that aided some officials to transact illegally and eventually delete the transactions from the system (Baker Tilly, 2014) This signifies lack of command in information technology on the part of the accountant or worse still an indication of lack of the values of integrity and honesty where one could say the accountant was part of, or gave consent to such transactions which were not put on record having disregarded the ownership of the entire system as put forward by Marian, S. F., Carmen, T., Gabriel, B., and Mihai, V. 2010)

A further analysis of the auditor's reports show that this challenge is still increasing over the years by approximately an average of $24 \%$ per annum. This shows how the internal controls of recording transactions in the government are getting loose by the day.

Trend for Challenge C1

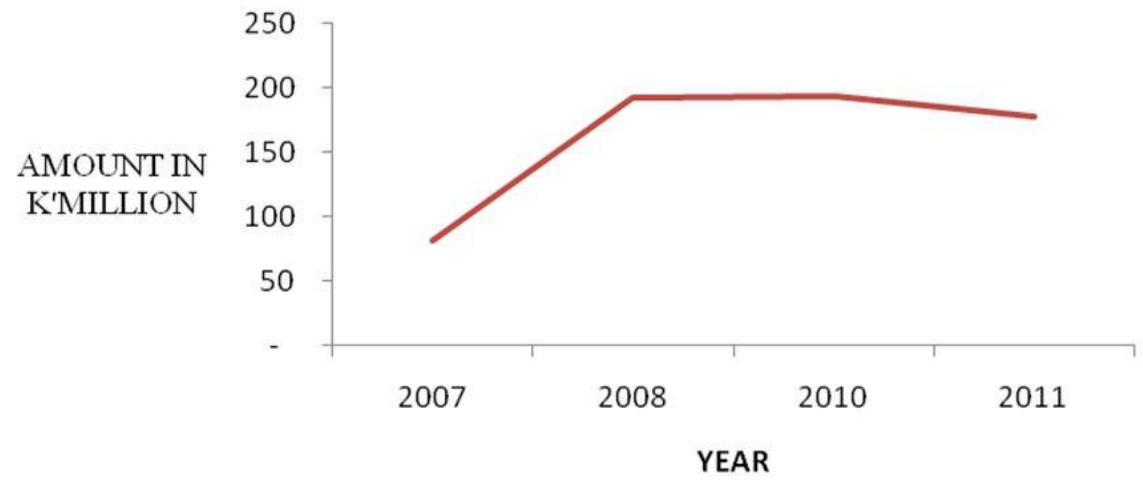

Figure 2. Trend for Unrecorded/unaccounted for transactions 2007-2011

\subsection{Challenge C 2, payments without proper supporting documents}

Reports from the auditors showed that payments of huge amounts of cash were recorded in the records but documents behind the transactions to explain the nature of the payment could not be traced.

This challenge was ranked second in magnitude amounting up to $15.5 \%$ of the total irregularities in Malawi Kwacha values, (see figure 1 above). Maintaining and producing documents for a transaction provides evidence as to the authenticity of such a transaction and the absence of these documents such as invoices from suppliers may highlight the inexistence of a transaction.

It is a norm that every payment made by an entity, whether in the private or public sector, should be supported by an invoice for the services provided or goods bought. Failure to produce these supporting documents implies that the payment(s) was undue and not necessary to be made.

The question that arises then is why the cheques were prepared and the signatories authorised the payment with full knowledge of the absence of supporting documents. This leaves one with more options from which to suggest the reasons, one of which being collusion, where individuals within a system come together and agree to override the controls with the aim of having personal gains. All at the expense of the general public, to whom they are accountable.

This could as well be attributed to undue pressure exerted on the accounting personnel by politicians who by virtue of their positions are deemed powerful beyond the law and set procedures, and therefore force their way into the public purse until they get hold of what they desire (Alemann, U. 2007).

Since the dawn of democracy in Malawi in 1993, there has been an influx of political interference in the government operations where public officers who are professionals in their fields are forced to act contrary to their professional requirements in order to please their political masters. It has recently been reported in Malawi that some political heavy weights and politically connected persons have been forcing public officers to remove names of needy students from the bursary scheme and replace them with their children or wards. ${ }^{2}$

This is just an iceberg on the sea as a lot of interference had been existing in the public systems but not much is reported because according to the Catholic Commission for Justice and Peace in Malawi, officers are not free and protected and do not report irregularities, especially arising from involvement of top politicians, to protect their jobs. Such incidences occur because politicians, especially those from the ruling party abuse their power and intimidate government officials

${ }^{2}$ Week end Nation News Paper, Politicians, elites, abuse Nsanje bursary scheme, issue Sept 27, 2014). 
into bending rules in their favour. ${ }^{3}$

This is the other challenge facing the twenty first century public sector accountant and requires a reconsidered view of his roles in order to perform to the public's best interest.

\subsection{Challenge C 4, Payments to Ghost Workers and Suppliers}

This challenge is ranked third from the analysis of the audit reports with a magnitude of $12.5 \%$ of the total irregularities in value. Literature has shown that this challenge is on the increase mainly due to high and growing levels of corruption in the procurement system, and the individual disregard of professional values and ethics on the part of the public officers.

Of late, reports have shown that corruption in Malawi over the past ten years has grown severely in the public service and it is wide spread by public officials in the procurement of goods and services. (Nawarz, F. 2012).

Existence of ghost workers and ghost suppliers over the past decade has been attributed to patronage networks which work through appointments in public sector positions and awards of lucrative contracts to political party loyalists (Hussein, M. 2005). Most influential individuals connected to ruling parties get government contracts without following the due process and eventually get full payment of the contract amount without completing or even performing the said contract.

Most of the ghost payments analysed in the years 2007 to 2011 were out of situations where salaries, allowances were paid to employees or workers whose identities could not be verified, payments to suppliers for no services performed, and worse still, payments to non-existing companies or suppliers.

As highlighted above, the increasing number of ghost workers and suppliers is attributed mostly to moral and ethical degradation of public officers, accountants inclusive, who engage themselves in such transactions. These officers take advantage of the gap which exists between the good legal frame work in ensuring effective public procurement that Malawi has, and the laxity in the implementation of such laws (Scorecard, 2011)

\subsection{Challenge C 6, Misallocated Funds (Used for Other Purposes Not Originally Intended For)}

As shown in figure 3 below, the use of funds for other purposes than those intended is on the increase in terms of the amounts involved. As the public sector's performance is measured by the value for money, which comprises the variables of economy, effectiveness and efficiency, using funds for other purposes (though not necessarily misappropriated) means that the funds are not used effectively and therefore the local tax payer, who was supposed to benefit from the initial purpose of the funds, loses out.

Among the funds that had been frequently used for other purposes were the deceased estate funds which are meant to help the poor families left behind by late government employees. For this reason, poor children and women were failing to access the funds for their own development activities.

The figure below shows the magnitude of the amounts of funds used for other purposes than those for which they were intended for. In public sector accounting and financial management, using the funds for other purposes is just the same as misusing them as the original targets would not be reached thereby falling short on the part of effectiveness in the VFM matrix.

The audit reports analyses reveal big gaps and weaknesses in the public sector accounting system where funds can be used not as budgeted for. This gives a loophole to officers to create own projects with the purposes of pocketing the funds for their own personal gains.

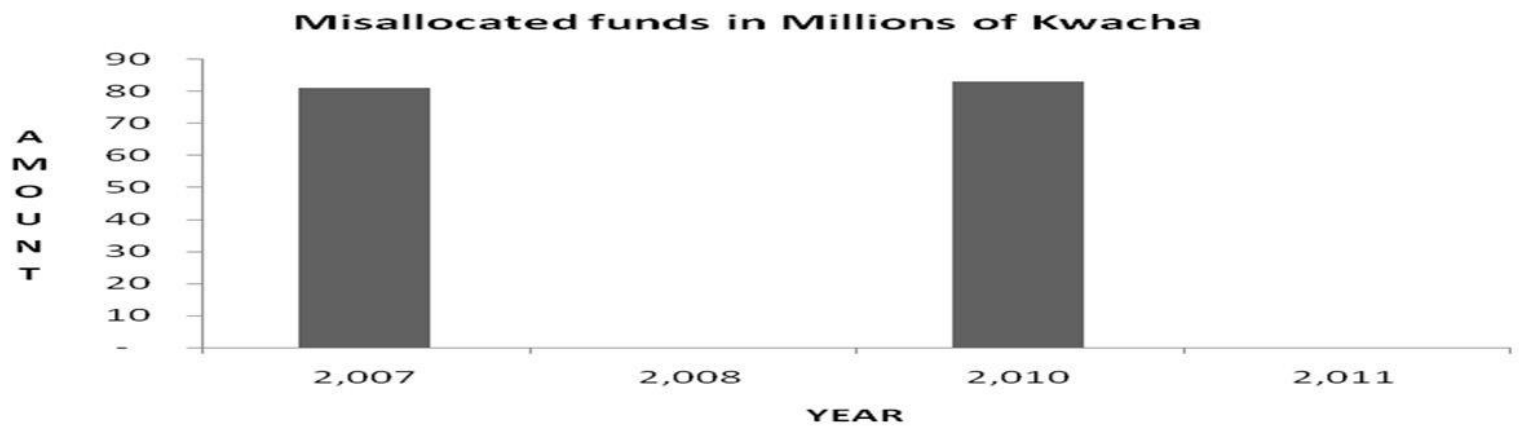

Figure 3. Misallocated Funds

\footnotetext{
3 (Malawi News Paper, Kachali under fire, issue September 272014.
} 


\subsection{Challenge C 7, Unauthorised Payments and Transactions}

In Malawi, significant public expenditures require legislative approval and a separate legislative committee, called the Public Accounts Committee (PAC), provides oversight of these public funds. It is alleged however, that most members of the Malawi legislature lack professional support staff to help them monitor the budget and other legislative processes (Scorecard, 2011).

This weakness on the part of the legislature to monitor the budget implementation creates rooms for public officers to make transactions and payments which were not initially approved. As seen from figure 4 below, this practice is on the increase as time passes and the overall effect is that most of the funds set aside for national development go down the drain without achieving their purpose.

Unauthorised payments in Million Kwacha

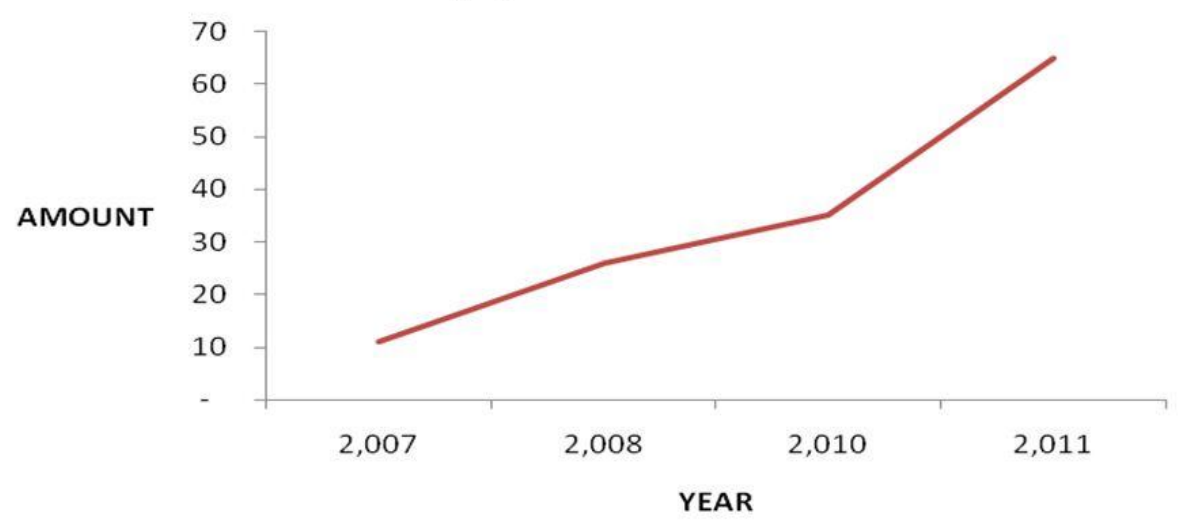

Figure 4. Unauthorised Payments

The unauthorised payments show a great weakness on the part of the accountant as the controller of resources. All the accountants need to do is to manage the few resources they have. They are to be ethical at all times because they are gatekeepers as they keep the money. If a coin goes out of the system, the accountant should know and be able to blow the whistle if the transaction is suspicious. ${ }^{4}$

\subsection{Challenge C 5, Items not presented For Audit}

The public officer in charge of public funds is required by the Malawi Public Finance Management Act 2003, to maintain proper financial management systems which involve keeping appropriate financial records, and where applicable, following generally accepted accounting principles. The officer should prepare financial reports for his or her department or ministry on time and provide the necessary schedules for audit purposes.

It was noted, however, that contrary to the requirements, the auditors were not getting access to other documents which they deemed necessary for their job and in other instances; the officers would not provide answers to auditors on some queries. This lack of co-operation between auditors and the public officers compromises the credibility of the accountant's work even though it might reflect the true picture of the state of affairs.

For the years under review in this paper, the values which the auditors have failed to audit and consequently not able to provide their opinion, keep on increasing at an average rate of $10 \%$ per annum. As a proportion of the total audit irregularities in amount, the items that were not presented for auditing amounted to $8.4 \%$ (see figure 1 above).

This challenge could be attributed to failure by accountants to adhere to deadlines and therefore lacking in demonstrating the values of accuracy and reliability as dictated by the profession (International Federation of Accountants, 2005).

\subsection{Challenge C 3, Misappropriations/Theft}

One of the most important roles of an accountant is that of a controller where the accountant institutes internal controls within the system to ensure safety of assets including cash, which is the most susceptible asset when it comes to theft. For the internal controls to effectively work however, the officers should acknowledge and honour the presence of such controls by demonstrating strict adherence to them.

The challenge now is not in the internal controls themselves, but the people who apply the controls. A lot of funds had

\footnotetext{
${ }^{4}$ Daniel Dunga, reported by Weekend Nation Newspaper, “Cashgate, a result of unethical leadership”, issue Sept 27, 2014)
} 
been reported stolen or misappropriated while internal controls were still in place.

The paper's analysis shows that irregularities arising from theft and misappropriations contribute a very little $0.4 \%$ of the total amounts. This however does not rule out the fact that funds in public institutions are being misappropriated or stolen because as already explained, it all depends on the ethical stand of the public officer in charge and the paper has shown that in recent years, professional ethics are not being applied when it comes to public resources.

In fact, all the audit irregularities analysed in this paper were a result of divergence from the ethical way of doing things and as can be seen from the figure 5 below, the total amounts of irregularities are on the increase year by year, reflecting the decline in ethical behaviour in doing professional work.

Growth of irregularities over time in Millions of Kwacha

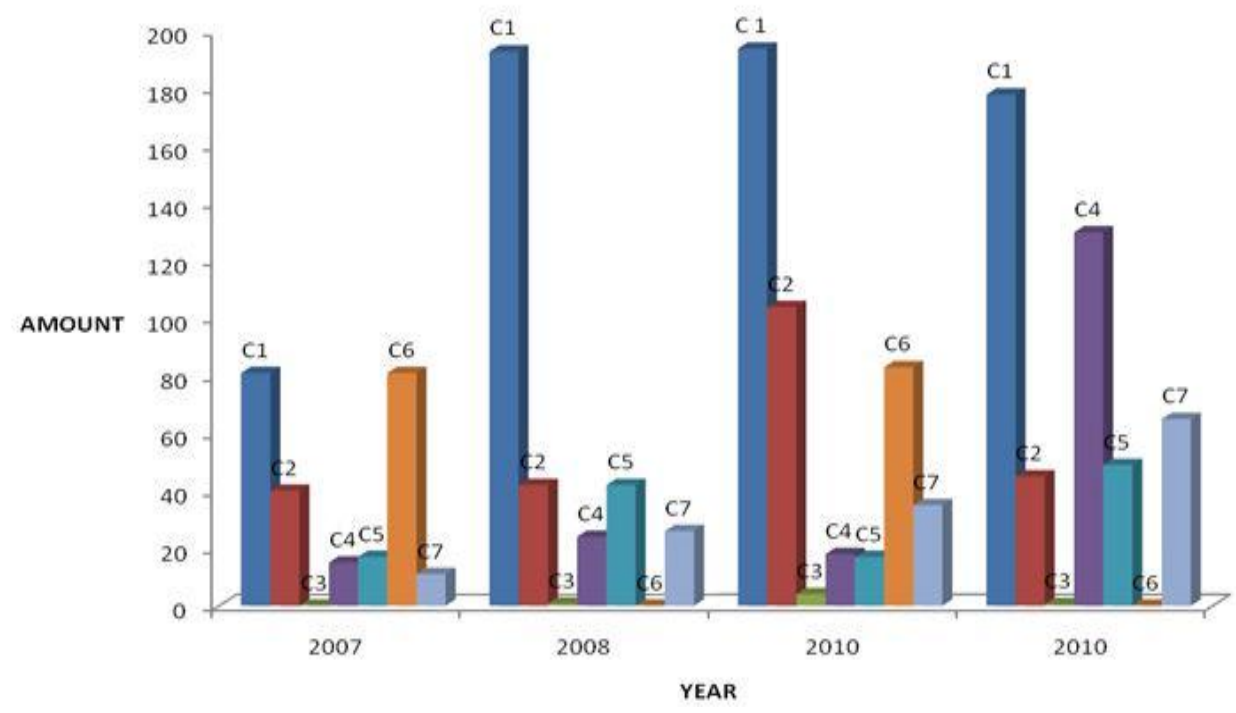

Figure 5. Growth of Irregularities Overtime

\section{Conclusions and Recommendations}

It is evident that the manager's actions and response to issues under his or her control depend on the situation at hand and this calls for professionals to properly evaluate the situations and environments surrounding them and act accordingly without really diverting from the professional ethics and norms.

An accountant's role in the public sector should not therefore be static in this dynamic environment. He or she needs to understand the nature of the surrounding in the working environment and act in the best interest of the local citizen who happens to be his ultimate employer though not influential. Officials in the public sector need to be reminded on a frequent basis that theirs is a fiduciary duty towards the country.

From the weaknesses analysed above in this paper, the researcher recommends that the accountants, just as other public office bearers should link their daily roles and tasks to ethics and morality. Accountants are required in almost every entity with the aim of providing control and better usage of the resources and it becomes worrisome when the accountant loses his ethical and normal values in performing his duties. Over and above the individual's personal conviction, taking an oath of office, especially for public service accountants, could enhance adherence to ethics and morality, where public interest could be the first priority in his daily endeavours.

It is also an undisputable truth that information technology has advanced to higher levels in the twenty first century and this enhanced business activities all over the world. Much as business life has been eased courtesy of information technology, fraud and theft has also grown rampant due to the same reason and on this I recommend accountants, especially in the public sector to have a very strong command on IT issues. The accountant, as a custodian of public resources should have an uncompromised knowledge of applying the use of computers and how to secure the information within a computer system (Coates, J.B., and Longden, S. G. 1989).

Accountants are still more encouraged and recommended to stick to their professional values regardless of the external pressures and influences from some other powers. This however could be possible if the public sector accountants had some backing or support from local professional bodies. Research has shown that the accountants in the public sectors bow down to pressure from political leaders and allow the system to be infiltrated simply because the accountant or officer concerned fears for their job. I recommend that in an attempt to maintain professionalism of accountants in the public sector, the local accountancy professional bodies should provide a cover for its accountants in the public sector and that they (the bodies) should ensure their members are protected from political powers. The accountancy bodies, 
being duly registered themselves, should set up a complaints department where accountants could report in case they are being threatened by some other influential people to act unprofessionally.

Accountants should as well incorporate the concept of management by objectives in their roles and in so doing they will be part of the overall strategy and objective of the institution they work for. They will have to own the success or failure of the institution they manage. To this point, the problem of unaccountability can be minimised, and hence the general public at large stands to benefit from the public resources under the accountant's control.

\section{References}

Alemann, U. (2007) Corruption within Public sector, EU, Directorate General Justice, Freedom and Security.

Andreason, L., \& Bladhl, A. (2005) The role of Management accountants in the Swedish public sector, Master thesis. School of Economics and Commercial Law, Goteborg University.

Baker, T. (2014) Report on Fraud and Mismanagement of Malawi Government Finances, National Audit Office, Malawi.

Bridisel, R. G., Popa, A., \& Pop, A. Budgetary and accounting experience in public sector-comparative case study http://kgk.uni-obuda.hu/system/files/BlidiselR_PopaA_PopA.pdf

Conceptual Frame work Task force Consultation paper 2, (2012) Measuring financial performance in the public sector financial statements. Conceptual Framework Task Force.

Coates, J. B., \& Longden, S. G. (1989) Management Accounting: The challenge of Technological Innovation, 1. Chattered Institute of Management Accountants, London.

Hepworth, N. (1993) Public sector accounting and financial control. Chapman and Hall, London.

Hussein, M. (2005) Combating corruption in Malawi-African Security Review

International Federation of Accountants (2005) The roles and domain of the professional accountant in business. Information Paper. http://www.ifac.org

Marian, S. F., Carmen, T., Gabriel. B., \& Mihai, V. (2010) Prevention and detection of fraudulent financial Reporting in the context of the financial crisis. Economic Science Series, 19(2), 906.

Millichamp, A. H., \& Taylor, J. B. (2008) Auditing $9^{\text {th }}$ Edition, BookPower, London

Nawarz, F. (2012) Overview of corruption and anticorruption in Malawi. (www.u4.no/.../overview-of-corruption-and-anti-corruption-in-malawi/)

Phiri, M., \& Chisala, R. (2009) Quick assessment of the Integrated Financial management information system. Report to OPC, Malawi.

Scorecard (2011) Malawi, Global Integrity, 2011. http://www.globalintegrity.org/report/Malawi/2011/scorecard

The Economist Intelligence Unit, From Bean Counter to Business Strategist: the changing role of the accountant. Marckle and Company. http://www.stewarttechnologies.com/Bean_Counter.pdf

The Malawi Constitution, Section, 184(1).

The Malawi Government Civil Service Charter

http://www.malawi.gov.mw/opc/images/Service\%20Charter/Service\%20charter.pdf

Vanstapel. F. (2004) Guidelines for internal control standards for the public sector. INTOSAI, Australia.

\section{(cc) $\mathrm{Br}$}

This work is licensed under a Creative Commons Attribution 3.0 License. 